\title{
ПСИХОЛОГІЧНА ПІДТРИМКА ГРОМАДЯН УКРАЇНИ, ПОСТРАЖДАЛИХ ВІД АНЕКСІЇ КРИМУ ТА КОНФЛІКТУ НА СХОДІ УКРӒ̈НИ
}

https://doi.org/10.37472/2707-305X-2019-1-1-4-1

\section{MAКСИМЕНКО}

\section{Сергій Дмитрович}

доктор психологічних наук, профресор, дійсний член (академік) НАПН України, академік-секретар

відділення психології, вікової фрізіології та десректології Національної академії педагогічних наук України; директор Iнституту психології імені Г.С. Костюка Національної академії педагогічних наук України, м. Київ, Україна

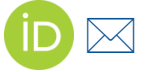

\section{СЕРДЮК}

\section{Людмила Захарівна}

доктор психологічних наук, професор, завідувач лабораторії психології особистості імені П.P. Чамати Iнсmumymy психології імені Г.С. Костюка Національної академії педагогічних наук України, м. Київ, Україна

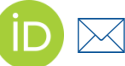

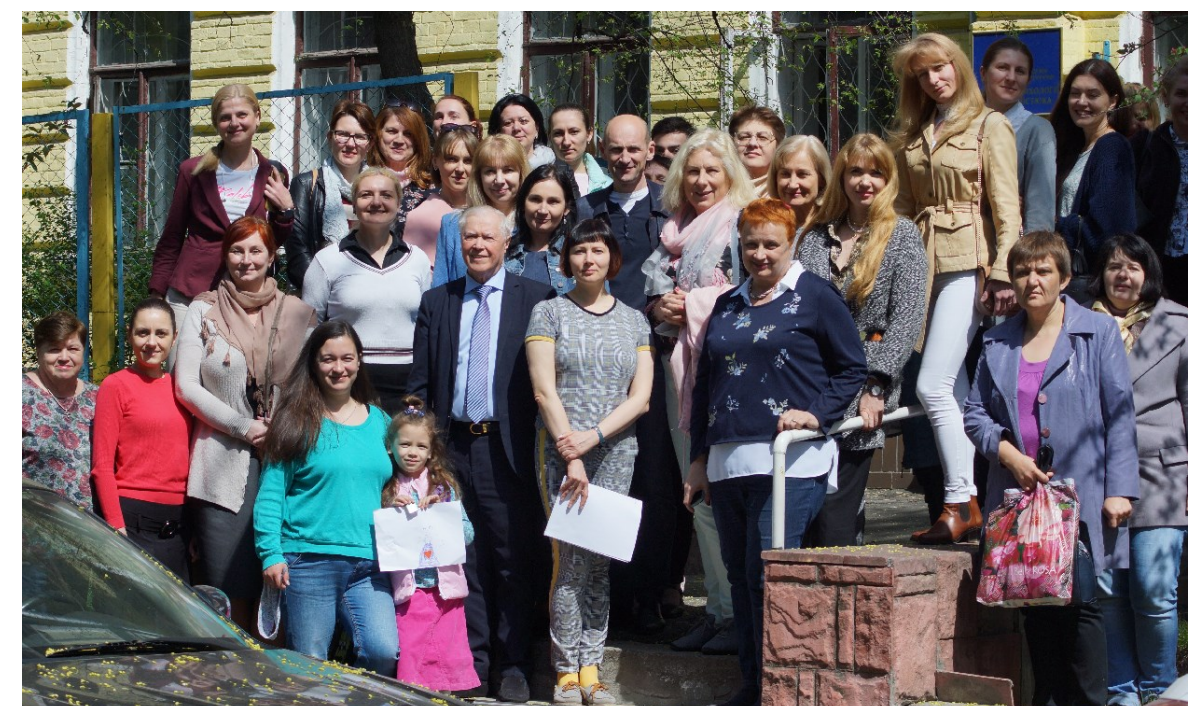

Анотація. Висвітлено зміст та завдання міжнародного проєкту, що виконується Інститутом психології імені Г.С. Костюка НАПН України, спрямованого на надання психологічної підтримки громадянам України, постраждалим від анексії Криму та конфлікту на Сході Україні. Реалізація проєкту в Україні сприятиме визначенню комплексної системи умов для самореалізації та соціалізації вимушених переселенців та людей, що зазнали насильства, створенню передумов для їх повноцінної адаптації до умов життя. Завдання проєкту спрямовані на: сприяння прочесу інтегращії внутрішньо переміщених осіб зі Східної України в місцевих громадах; підвищення соціальної активності внутрішньо переміщених осіб та зміиненню їхньої спроможності до протидії насильства щодо жінок; підвищення спроможності внутрішньо переміщених осіб брати участь у бізнесовій діяльності, діяльності громадянського суспільства, державних або муніципальних установ; допомогу місцевим органам влади та жіночим організаціям у досягненні актуальних завдань щодо жінок, миру та безпеки.

Розкрито зміст та результати роботи з внутрішньо переміщеними особами, що відбувалися в ході реалізації проєкту.

Ключові слова: психологічна підтримка; адаптація; соціалізація; реабілітація; внутрішньо переміщені особи; анексія Криму; конфлікт на Сході України.

Інститут психології імені Г.С. Костюка НАПН України спільно 3 Клайпедським університетом (Литовська Республіка) виграв конкурс на виконання трирічного проєкту «Підтримка громадян України, постраждалих від анексії Криму та конфлікту на Сході України» («SUPPORT FOR UKRAINIAN CITIZENS AFFECTED BY THE ANNEXATION OF CRIMEA AND THE CONFLICT IN EASTERN UKRAINE», 2018 р., проєкт № 13). Проєкт фінансується Міністерством закордонних справ Литовської Республіки. Конкурс відбувся в кінці 2018 р. Вимогами участі в 
конкурсі були оригінальність ідеї проєкту, наявність досвіду реалізації проєктів подібного характеру та досвіду співпраці литовський вчених з партнерами з Україні.

Мета проєкту полягає в тому, щоби допомогти людям, особливо жінкам, які постраждали від анексії Криму та конфлікту на Сході України, інтегруватися в місцеві громади. Адже, за даними Міністерства соціальної політики України, у 2018 р., внаслідок військового конфлікту на сході країни кількість внутрішніх переселенців в Україні з Донбасу і Криму становила близько 1,5 млн осіб. Унаслідок травматичного досвіду ці люди переживають стани, які спричиняють нестабільність і втрату контролю над ситуацією, власним життям, втрату автономності та суб'єктності, порушення ідентичності, розгубленість, психосоматичні розлади, порушення адаптації, у тому числі й посттравматичний стресовий розлад. Як наслідок цього, простежуються також тенденції до поширення насильницьких дій у сім'ї, у стосунках батьків і дітей, між членами подружжя та у міжособистісній взаємодії загалом. Підґрунтям таких поведінкових проявів часто буває брак довіри (або втрата довіри до будь-чого / будького). Тому у місцях розміщення переселенців виникає багато конфліктів, мешканці переважно живуть ізольовано, мало спілкуються між собою, відчувається відчуженість і недовіра один до одного, до психологів, до представників влади тощо. Більшість із них також зіштовхуються 3 труднощами та бар'єрами на ринку праці, в системі освіти тощо. Питання перекваліфікації дуже важливе для внутрішньо переміщених осіб, оскільки вони переїхали з індустріальних регіонів, і їх професійні навички на новому місці проживання часто бувають незатребуваними. Надання їм можливості подальшого працевлаштування, безперечно, матиме позитивний вплив на зміцнення здоров'я, особистісний розвиток, психологічне благополуччя та повноцінну інтеграцію в суспільство.

Маємо надію на те, що реалізація проєкту в Україні сприятиме визначенню комплексної системи умов для самореалізації та соціалізації вимушених переселенців і людей, які зазнали насильства, створенню передумов для їх повноцінної адаптації до умов життя, формування у них навичок стресостійкості та життєстійкості.

Реалізація проєкту також стане основою для розроблення рекомендацій для покращення системи профорієнтації, професійної підготовки, підвищення кваліфікації та працевлаштування постраждалих категорій громадян. Адже певну кризу переживає і професійне середовище педагогів, психологів, соціальних працівників, суть якої полягає у відсутності або недосконалості наявних методик роботи з сім'ями та дітьми, які постраждали від збройного конфлікту, та особами, що зазнали насильства.

Реалізація завдань проєкту спрямована на:

1. Сприяння процесу інтеграції внутрішньо переміщених осіб зі Східної України в місцевих громадах.

2. Підвищення соціальної активності внутрішньо переміщених осіб, особливо жінок, та зміцненню їхньої спроможності до протидії насильству щодо жінок.

3. Підвищення спроможності внутрішньо переміщених осіб, особливо кримських татар, брати участь у бізнесовій діяльності, діяльності громадянського суспільства, державних або муніципальних установ.

4. Допомогу місцевим органам влади та жіночим організаціям у досягненні актуальних завдань щодо жінок, миру та безпеки.

У рамках реалізації проєкту фахівці Клайпедського університету разом із фахівцями Інституту психології імені Г.С. Костюка НАПН України працювали із внутрішньо переміщеними людьми із Криму та Донбасу. Відбулись зустрічі, змістовні групові та індивідуальні форми роботи, звичайне міжлюдське спілкування.

Між Інститутом психології імені Г.С. Костюка НАПН України та Клайпедським університетом було підписано угоду про співпрацю та координацію проєкту.

У результаті зустрічей із внутрішньо переміщеними людьми було визначено актуальні соціально-економічні та психологічні проблеми, з якими вони зазвичай стикаються. Було виявлено, що найбільш гострими залишаються проблеми: прийняття ситуації «свій - чужий»; втрати ідентичності; адаптації на новому місці; втрати відчуття стабільності і безпеки; сімейних конфліктів тощо.

У ході роботи визначено психологічні способи надання їм допомоги, напрями подальшої роботи: соціалізація та інтеграція дітей і підлітків; профорієнтація; організація груп підтримки; тематичний жіночий клуб (жіноче здоров'я, сімейні конфлікти, вікові кризи та ін.); організація груп психоедукації - (освітні групи: як допомогти собі та іншим, навчитись навичкам саморегуляції); залучення психологів з числа переселенців 
до роботи груп підтримки; організація оздоровчих, розвиваючих програм для дітей, підлітків; проведення досліджень з питання «Що і як змінилося у ставленні до ВПЛ через 5 років». Також були проведені семінари-тренінги для психологів і всіх зацікавлених фахівців «Перша психологічна допомога: досвід міжнародних організацій» та «Кризове консультування в екзистенційно-аналітичному підході».

У липні 2019 р. у м. Клайпеда відбувся літній реабілітаційно-оздоровчий табір для жінок, метою якого було сприяння соціальній активності жінок та зміцненню їхньої спроможності щодо протидії насильству. Під час роботи в таборі відбулося знайомство з Клайпедським університетом, зустріч з ректором, керівником і виконавцями проєкту. Терапевтична робота та навчальні заняття поєднувалися з цікавими екскурсіями та знайомством з Литвою.

Із відгуків жінок-учасниць літнього табору в м. Клайпеді... «Клайпеда затишно влаштувала- ся якраз в тому місиі, де Куршська коса зустрічається з Балтійським морем. Вона ніби приймає в свої обійми і ніжно тримає, заспокоюючи всі можливі тривоги, даруючи гармонію $i$ спокій...»; "нашій групі, яка приїхала сюди з України, ця гармонія і спокій були потрібні, як нікому іншому. Адже ми зіткнулися в своєму житті з найбільшим жахом, який тільки можна собі уявити - з війною, що прийщла в наш дім на Сході України...»; "...дяя мене проєкт виявився не просто «ковтком свіжого повітря», а став "кисневою маскою», що захищає від n'ятирічного колообігу «Київ-Луганськ». До того ж, подорож в Литву - че моя перша поїзка за кордон...»; "...ия поїздка пробудила в мені різні почуття, дала можливість переключитися, познайомитися $і$ поспілкуватися з колегами $i$ жінками, які також, як і я, залишили свій затишний дім, друзів і почали 5 років тому нове життя в столиці...».

\title{
PSYCHOLOGICAL SUPPORT FOR UKRAINIAN CITIZENS AFFECTED BY CRIMEA ANNEXATION AND THE CONFLICT AT THE EASTERN UKRAINE
}

\author{
Serhii Maksymenko \\ DSc in Psychology, Professor, Full Member (Academician) of NAES of Ukraine, Academician Secretary of the Division \\ of Psychology, Age Physiology and Defectology, National Academy of Educational Sciences of Ukraine, Kyiv, Ukraine; \\ Director, G.S. Kostiuk Institute of Psychology of the National Academy of Educational Sciences of Ukraine, Kyiv, Ukraine \\ Liudmyla Serdiuk \\ DSc in Psychology, Professor, Head of the Laboratory of Psychology of Personality, G.S. Kostiuk \\ Institute of Psychology of the National Academy of Educational Sciences of Ukraine, Kyiv, Ukraine
}

Abstract. The content and objectives of the international project implemented by G.S. Kostiuk Institute of Psychology of the National Academy of Educational Sciences of Ukraine and aimed at provision of psychological support to Ukrainian citizens affected by the annexation of Crimea and the conflict at the Eastern Ukraine are described. The project implementation in Ukraine will help to define a comprehensive system of conditions for selfrealization and socialization of internally displaced persons or abused people, and create preconditions for their full adaptation to life situations. The project objectives are: to facilitate integration of internally displaced persons from the Eastern Ukraine into local communities; to enhance their social activity and strengthen their ability to combat violence against women; increase the capacity of internally displaced persons to participate in business, civil society, governmental or municipal institutions; to assist local authorities and women's organizations in achieving current challenges for Women, Peace and Security. The content and results of the project work with internally displaced persons are revealed.

Keywords: psychological support; adaptation; socialization; rehabilitation; internally displaced persons; annexation of Crimea; conflict in the Eastern Ukraine. 